\title{
PROFESSIONAL WORK
}

\section{MAREK STACHOWSKI}

Jagiellonian University in Kraków marek.stachowski@uj.edu.pl

\section{Slavic languages in contact, 8: Turkish -r- > Serbian, Croatian - $r$}

Abstract: Even though there is no sonantic $r$ in Turkish, some Croatian and Serbian reflexes of Turkish loanwords display an $r$. Such examples form two typologically different groups. One of them can be explained by a purely Slavic phonological proportion. The other group, however, can only be characterised in terms of Turkish phonetics, but its full explanation escapes our analyses.

Keywords linguistics, Turkish, Balkan Slavic, language contact, phonology 


\section{The problem and the material}

It was almost fifty years ago that Stanisław Stachowski presented a group of Turkish (= Tksh.) words with the vowel $-\imath$ - whose Serbian ${ }^{1}$ and Croatian (= SC) reflexes have the consonant $-r$ - at this place (Stachowski 1973: 43sq.). Some of them are archaic or dialectal words, some are accepted even in the modern language usage (for dialectal areas see the material and sources in Petrović 2000: 176). Let us first adduce them all here: ${ }^{2}$

[1] (h)ršum 'exclamation' < older Tksh. ${ }^{\star} h ı s ̧ u m=$ modern Tksh. hışım 'anger, fury';

[2] jagrz 'black or chestnut horse' < older Tksh. yagız = modern Tksh. yağız id.;

[3] krbla 'qibla, direction towards the Kaaba' < Tksh. Kible id. $\|$ krblenama 'compass' < older Tksh. kıblenüma 'compass showing the direction of Mecca';

[4] krlič krluč 'sabre; sword' < Tksh. kılıç id.;

[5] krna 'henna' < Tksh. kına id.;

[6] krsmet 'fate, destiny' < Tksh. kısmet id.;

[7] kršla 'casern' < Tksh. kışla id.;

1 In my article, I use the name "Serbian" in pluricentric sense, that is, the term encompasses the Shtokavian variants in Serbia, Bosnia and Herzegovina as well as in Montenegro. One of the anonymous reviewers suggests that the use of this term might have been a politically motivated decision, which, of course, it is not. It is not possible to distinguish between, say, Bosnian and Serbian in the seventeenth, eighteenth or nineteenth centuries. The use of a twenty-first century term like "BCMS" (= Bosnian-Croatian-MontenegrinSerbian) in a seventeenth century context would simply be an anachronism and thus a grave methodological mistake. I do not feel the need to address his other minor objections, since I absolutely fail to see their relevance. - The other reviewer had no objections of this sort, and I am very grateful to him.

2 Croatian and Serbian prosodic symbols are omitted here. Croatian and/or Serbian words stand at the beginning of every item which is not every time signaled by the abbreviation "SC". The language called "Ottoman Turkish" in Stachowski 1973 is called "older Turkish" here because "Ottoman Turkish" is ambiguous (see Stachowski 2019a). 
[8] kršlak 'winter camp/site' < Tksh. kışlak id.;

[9] krzamak 'measles' < Tksh. kızamık (dial.) kızamak id.;

[10] krzil 'red' < Tksh. kızıl id. ॥ krzilbaši 'Qizilbash (a religious group)' < Tksh. kızılbaş id.;

[11] krzluk 'virginity' < older Tksh. kızluk= modern Tksh. kızlık id.;

[12] sakrlisati se 'to feel embarrassed' < Tksh. sıkıl- *sakıl-id.;

[13] sakrz 'species of gourd' < Tksh. sakız kabağı id.;

[14] srklet 'anxiety, nervousness' < Tksh. siklet 'weight; load';

[15] zrt 'disgusting, disliked' < Tksh. $z \imath t$ '1. opposite; 2. disliked'.

The question is why and under what circumstances Turkish - - - was rendered by $-r$ - in Croatian and Serbian. The change observed in the words cited above has not found an explanation as yet. Some other words, namely ones with $-1 /$ ir- in Turkish, were subject to a similar process. Only two examples for the change of Tksh. $\imath r->$ SC $r$ - are known in anlaut position (Stachowski 1973: 42):

[16] $r z$ 'respect' < Tksh. $\imath r z$ id.;

[17] $r s b z$ 'dishonourable' < Tksh. dial. $\imath r s ı \sim$ เrzsız = Tksh. lit. hırsiz 'thief' (Stachowski 2019: 172: < Ar. 'ird 'honour, dignity, honesty').

The same change can be more frequently observed in the wordmedial position (Stachowski 1973: 40):

[18] bazrđan 'merchant' < older Tksh. *bazirgân bezirgân id.;

[19] čekrdak '(fruit) core with stones' < Tksh. çekirdek 'fruit kernel';

[20] lakrdija 'language, dialect' < Tksh. lâkırdı 'talk, chatter, gossip';

[21] pistrma (? pro: pastrma) 'dried and spiced beef' < Tksh. pastırma id.; 3

On the etymology and folk etymology of Turkish pastırma see Stachowski 2013: 179-182. 


\section{KNJǏ̌EVNI JEZIK 31, 2020. (49-55)}

[22] srča 'glass' < Tksh. sırça id.;

[23] šegrt 'apprentice, learner' < Tksh. *şegirt şakirt id.

\section{The Slavic background}

Modern reflexes of the Proto-Slavic sonant ${ }^{*} r$ are pronounced as sonants in Croatian and Serbian but receive a short vowel at the onset in Bulgarian and Macedonian, as in SC crn = Bulg. čăren, Mac. cărn 'black'; SC srce = Bulg. Mac. sărce 'heart', and so on (Popović 1960: 305, Nr. 6). That means that Croats and Serbs will probably have elaborated the following correspondence in their language awareness: foreign -ăr- $=$ our $-r-$. The conjecture that this proportion influenced adaptation of Turkish words lies near at hand.

\section{The situation with Turkish}

Turkish and Turkic vowels $a$ and $\iota$ are often, esp. in allegro speech, reduced (= mid-centralised) and, thus, perceived by non-Turks as a sound between high and low. They are mostly rendered with «1 〈a in writing. The phenomenon is usually called the $a \sim 1$ alternation. That is the case with the first syllable in [12] sakrlisati se. One can scarcely decide whether the Turkish etymon sikıl- was actually pronounced ${ }^{\star}$ săkıl- or just ${ }^{\star}$ sakıl-.

\section{The -I/ir- group}

The $-1 /$ ir- group comprises words [16]-[23]. It seems to very well match our conjecture made above. All these words were presumably classed together with Bulgarian and Macedonian -ăr- words (that is, e.g., [16] Tkish. $\imath r z$ was interpreted as ${ }^{*} \breve{r} r z$, [23] Tksh. *şegirt as ${ }^{*}$ şegĕrt or *şegărt and so on) which made possible and logical treating them as $-r$ - words in Croatian and Serbian.

4 Minor phonetic differences between the Bulg. $\breve{a}$ and the Mac. $\breve{a}$ are ignored here. 


\section{The $-1 / \mathrm{i}$ - group}

The $-1 / i$ - group comprises words [1]-[15]. Here, no $r$ stands after $-\imath / i$ - in the Turkish etymon and, thus, no natural explanation of the change of that vowel in $-r$ - can be given. My first thought was to find out by what phonetic features all these words are spanned. The result of this approach is, however, rather modest. On the other hand, some features seem to be regular, and one should not probably ignore them. Below, I am going to present how I imagine specific evolutionary stages, even if not every aspect of the evolution could sufficiently be understood so far.

Because the Tksh $r$ sound is pronounced as an alveolar flap $[r]$ the contact of the tongue with the alveolar ridge is very brief. The tongue does not sink immediately after plosion but, instead, it creates a channel which causes a short frication of the air stream. The result is $\left[r^{f}\right]$; it can best be heard in the word-final position. A foreigner, unaccustomed to the auditively weak Turkish flap, generally tends to interpret what he hears as $[\mathrm{S}]]$ (or just $[\delta]$ ) rather than $\left[\mathrm{r}^{\mathrm{f}}\right]$. Otherwise, it can be assumed that foreigners accustomed to the flap reinterpreted Turkish $[\delta]$ as a lax articulatory variant of $\left[\mathrm{f}^{\complement}\right] \sim[\mathrm{f}]$.

Then, words like [1] Tksh. *hışum, [7] Tksh. kışla and [8] Tksh. kışlak were first examples of misinterpretation as alleged ${ }^{\star} h \imath$ rşum, ${ }^{\star} k ı r s ̧ l a$ and ${ }^{*} k \imath$ ş̧lak, respectively. Let us accept a symbolic notation: $\mathrm{K}=k, g, h ; \mathrm{I}=$ $\imath, i ; S=s,, s, z$. Then, the change in Phase I was as follows: Turkish $K-I-s$, , reinterpreted as ${ }^{\star} K$-Ir $r$ ş in Slavic $>$ Serbian, Croatian $K$ - $r$-ş.

Words with fricatives $s$ and $z$ came second: Tksh. [2] yagiz, [6] kısmet, [9] kızamık, [10] kızıl, kızılbaş, [11] kızluk; [13] sakız. They created Phase II: Turkish $K-I-s / z$, reinterpreted as ${ }^{\star} K-I r-s / z$ in Slavic $>$ Serbian, Croatian $K-r-s / z$.

Both phases (I and II) can be summarised as follows: Turkish $K-I-S>$ reinterpreted as ${ }^{\star} K-I r-S$ in Slavic $>$ Serbian, Croatian $K-r-S$.

Phase III encompasses words in which the vowel -1 - is followed by a nasal or lateral consonant: [4] kılıç, [12] sıkıl-and [5] kına. I think that was possible because $r$ and $l$ are articulated at approximately the 


\section{KNJǏ̌EVNI JEZIK 31, 2020. (49-55)}

same place as $\check{s}$ and $s$ are. A special case is [3] Tksh. Kıble $\sim$ kıblenüma; here, $l$ is somewhat remote because of $b$. It remains unclear why this fact did not form an obstacle in changing $-1->-r-$. The model of Phase III is: Turkish $K-I-l / n>$ Serbian, Croatian $K-r-l / n$, with one special case [3]: Turkish $K-I-b l>$ Serbian, Croatian $K-r-b l$.

Two Turkish words are left for Phase IV: [14] siklet and [15] zıt. Here, two changes should be assumed: the Turkish model K-I-S would have in Slavic been extended to sequences in the reverse order: $>S-I-K$ and, additionally, modified to $S-I-t$ in [15]. However, this solution does not appear realistic and convincing. It is probably better to stop with Phases I-III.

\section{Some conclusions}

The scenario outlined above is acceptable but not underpinned by philological facts. Moreover, one cannot say why the most words in the $-i / i$ - group have $k$ as the word initial sound. More precise solutions should probably be sought in Slavic dialects rather than in Turkish, that is the change of Tksh. -1-> Slavic - $r$ - seems to result from adaptation attempts based on auditory perception of foreign sounds rather than from a phonetic change or situation in the donor language.

\section{References}

Petrović, Snežana, (2000): "Some problems of Balkan Turcisms", in: Tzitzilis, Ch.; Symeonidis Ch. (ed.) Akten des Internationalen Kongresses "Balkanlinguistik. Synchronie und Diachronie" 30 Oktober - 1 November 1997 Thessaloniki, Thessaloniki, 175-187.

Popović, Ivan, (1960): Geschichte der serbokroatischen Sprache, Otto Harrassowitz, Wiesbaden.

Stachowski, Marek, (2013): "David L. Gold's English, Jewish and other etymologies”, Studia Etymologica Cracoviensia 18, 167-195.

- (2019): Kurzgefaßtes etymologisches Wörterbuch der türkischen Sprache, Księgarnia Akademicka, Kraków. 
- (2019a): "Slavic languages in contact, 2: Are there Ottoman Turkish loanwords in the Balkan Slavic languages?", Studia Linguistica Universitatis Iagellonicae Cracoviensis 136, 99-105.

Stachowski, Stanisław, (1973): Fonetyka zapożyczeń osmańskotureckich w języku serbsko-chorwackim, Ossolineum, Wrocław Warszawa - Kraków - Gdańsk.

Author's statement on the absence of conflicts of interest and compliance with general codes of ethics: The author confirms that there is no actual or potential conflict of interest related to this text and that the text is written in accordance with the codes of ethics according to the recommendations of COPE (Committee of Publishing Ethics). 